\title{
Up the Ladder: An Autobiography by Frank Anderson \\ Saskatoon:
}

A Gopher Publication (1997) 231 pp.

Reviewed by Bob Gaucher

$\mathbf{I}^{\mathbf{n}}$

1935, at the age of 17, Frank Anderson was convicted of capital

murder for the death of a prison guard killed in a failed jailbreak from a Manitoba provincial gaol. Orphaned amidst the turmoil of prairie drought and economic depression of the 1930s, Anderson was serving a one year term for minor "hobo" and railrider thief charges at the time of the attempted escape. His original death sentence was later commuted, largely because of his age and circumstances.

On the surface this is a remarkable, though traditional tale of damnation and redemption. This is a saga of every man's journey beyond that decisive moment and its possible fatal result. Most of us have experienced moments in our youth, where good luck and the Grace of God saved us from serious harm or perdition. Anderson's vivid account of coping with such a fatal mistake draws us into his story. During the fifteen years he served at Saskatchewan Penitentiary, Anderson completed high school and all but two science courses need for a general B.A. from the University of Saskatchewan. This was unheard of in Canada's penitentiaries at that time. Education proved to be his route out of prison and upon release he attend the University of Toronto, where he graduated in 1957 with an MSW degree. In 1974, Frank was appointed to the National Parole Board of Canada, where he served as a regional member until retiring in 1979.

Anderson's considerable talents are evident in the varied activities of his life; in his college teaching and course design; in his involvement with the creation of Canada's social services net, and in his extensive research and writing on crime and local social histories. In the 1950s MacLean Magazine published a feature article on him, and C.B.C. Radio aired a week long series on his life. His Frontier Books series of local histories and stories became the basis for a successful thirteen week television series in the 1960s.

An historian and archivist, as well as a publisher, Anderson received awards for his historical research and publications from the Alberta Historical Society, and the North American State and Local History Society in the USA. He researched the use of capital sentences 
in Canada and made an important intervention into the debate over capital punishment with Hanging In Canada (1973).

However, this up the ladder voyage of a depression era orphan is much more than the personal saga of Frank Anderson. Written in his late seventies, this is a studied reflection on his life and times. This is a social history of the era of penal reform in Canada, told from the shifting perspective (margin-centre) of a former prisoner. Indeed, Frank was a role model for the goals of the new reformative penology, and an important contributor to the professional and public debate surrounding its attempted implementation. Anderson was instrumental in integrating the reformative/rehabilitative discourse of the prison reform movement with the broader public discourse on social welfare.

I found his account of the legendary and infamous Warden Lt. Colonel Cooper and his penal code, insightful, and revealing of penal management practices and convicts' responses to it. His portrayal of prison custom on the Canadian prairies during 1930-1950 is an important addition to our penological study of this era. I used this text in a large second year university course which provides an introduction to Canada's penitentiary system. It was very well received ("interesting" - "fascinating") and covered an important period in Canadian penal history which is only accessible through textbooks. I recommend it as a good read and as an academic text. 